June $195^{I}$

Vol. LXV. No. 6

\title{
The Journal of
}

\section{Laryngology and Otology}

EDITED BY

WALTER HOWARTH

ASSISTANT EDITOR

R. SCOTT STEVENSON

- WITH THE COLLABORATION OF

G. H. BATEMAN V. E. NEGUS R. G. MACBETH

\section{Contents}

OBSERVATIONS ON ABDUCTOR PARALYSTS OF THE VOCAL CORDS . . . . . . . .

A. F. WIILIAMS

Some OBservations on the Conduction Mechanisi OF THE EAR . . . . . . . . . . .

N. W. GILL

LATENI TUBERCULOSIS IN TONSILS AND ADENOIDS .

A. BeLAL

LIPOMA OF THE LARYNX . . . . . . . . . . MACONIE

CIINICAI RECORDS-

LYMPHOSARCOMA OF THE ETHMOID * a - ALEXANDER R. HARPER

OTOGENIC MENINGITIS-A REPORT OF FOUR

Recent CAses . . . . . . . . A. Appleton

SOCHETES' ProcehDINGS-

ROYAT, SOCIETY OF MEDICINE-SECTION OF LARYNGOLOGY

ABSTRACTS-

THE EAR

TRACHEA AND BRONCHI

The CEsophagus

Miscellaneous

London

Headley Brothers Ltd

Io9 Kingsway $\mathrm{W} \mathrm{C}_{2}$ 


\section{The Journal of \\ Laryngology and Otology}

(Founded in 1887 by MORELL MACKENZIB and NORRIS WOLFENDEN) EDITED BY

WALTER HOWARTH

ASSISTANT EDITOR

R. SCOTT STEVENSON

WITH THE COLLABORATION OF
G. H. BATEMAN
V. E. NEGUS
R. G. MACBETH

1. Original Articles are accepted on the condition that they have not been published elsewhere.

2. Manuscripts should be typewritten, on one side only of the paper, and well spaced.

The Harvard system of recording references should be used, e.g. Green, G., and Brown, D. (I95 I) 7. Laryng. and Otol., 65, 33 .

It is most important that authors should verify personally the accuracy of every reference before submitting a paper for publication.

3. Galley proofs and engraver's proofs of illustrations are sent to the author. Corrections, which should be kept to a minimum, must be clearly marked, and no additional matter added.

4. Blocks illustrating articles are normally paid for by the Jotunal. Authors may, however, be required at the Editor's discretion, to contribute towards the cost of these in cases where this is particularly heavy.

5. Orders for reprints should be sent when returning galley proofs, and for this purpose special forms are supplied.

6. Authors of original communications on Oto-Laryngology in other journals are invited to send a copy, or two reprints, to the Journal of Laryngology. If they are willing, at the same time, to submit their own abstract (in English, French, Italian, or German) it will be welcomed.

7. Editorial communications may be addressed to THE EDrror, foumal of Laryngology, c/o HeAdLeY BRothBrs LTD, log Kingsway London $\mathrm{W} \mathrm{C}_{2}$.

8. The annual subscription is three guineas sterling, post free, and is payable in advance.

9. Single copies will be on sale at $7 \mathrm{~s}$. $6 \mathrm{~d}$. each; copies of parts up to Vol. LXIII may be purchased at 4 s, each.

10. All subscriptions, advertising and business communications should be sent to the publishers, HeADLeY BRothers LTD, IOg Kingsway London W C 2 .

Uniled States of America

Orders for this foumal may be sent either through a local bookseller, or to Messrs. G. E. Stzchert \& Co., 31-33 East roth Street, New York, or they may be sent direct to the publishers, HEADLEY BROTHERS LTD, rog Kingsway London $\mathrm{WC}_{2}$, England. 


\section{AMPLIVOX MODEL 6 I \\ THE CLINICAL AUDIOMETER OF INTERNATIONAL REPUTE}

"Messrs. Amplivox were among the first firms to produce an audiometer in this country, and their larger model is one of the best instruments of the kind now made in the world at a competitive price." -The LANCET, 23-12-50.

- Eleven exact test frequencies 125-12,000 c.p.s.

- Simplified hearing loss dial. The same set of figures is read for both bone and air conduction at all frequencies, and for speech.

- Bone conduction tests can be made from 125-4,000 c.p.s.

- Masking Tone calibrated in decibels, permitting accurate control of masking.

- Double Air receivers enable test tones to be switched instantly from ear to ear.

- Speech test circuit monitors speech level, permitting accurate measurement of hearing loss for speech.

- Loudness Balance Control establishes presence of recruitment in monaural deafness.

- Automatic voltage compensator.

Recruitment Test Set accessory establishes presence of recruitment by amplitude modulation, enabling each ear to be tested independently.

Speech Turntable and Englishmade Harvard Spondee records also available.

Full details are available from the manufacturers who will gladly arrange demonstrations if required.

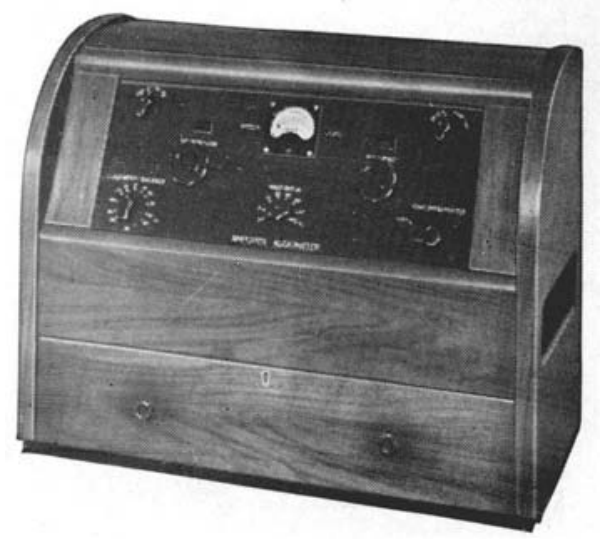

\section{The Basic Instrument of Modern Otology}

ACCURATE • COMPLETE • SIMPLE TO OPERATE

AMPLIVOX LTD., 2 BENTINCK ST., LONDON, W.I (Welbeck 259I)

Please mention The Journal of Laryngology when replying to advertisements 


\section{Child Co-operation in Audiometry}

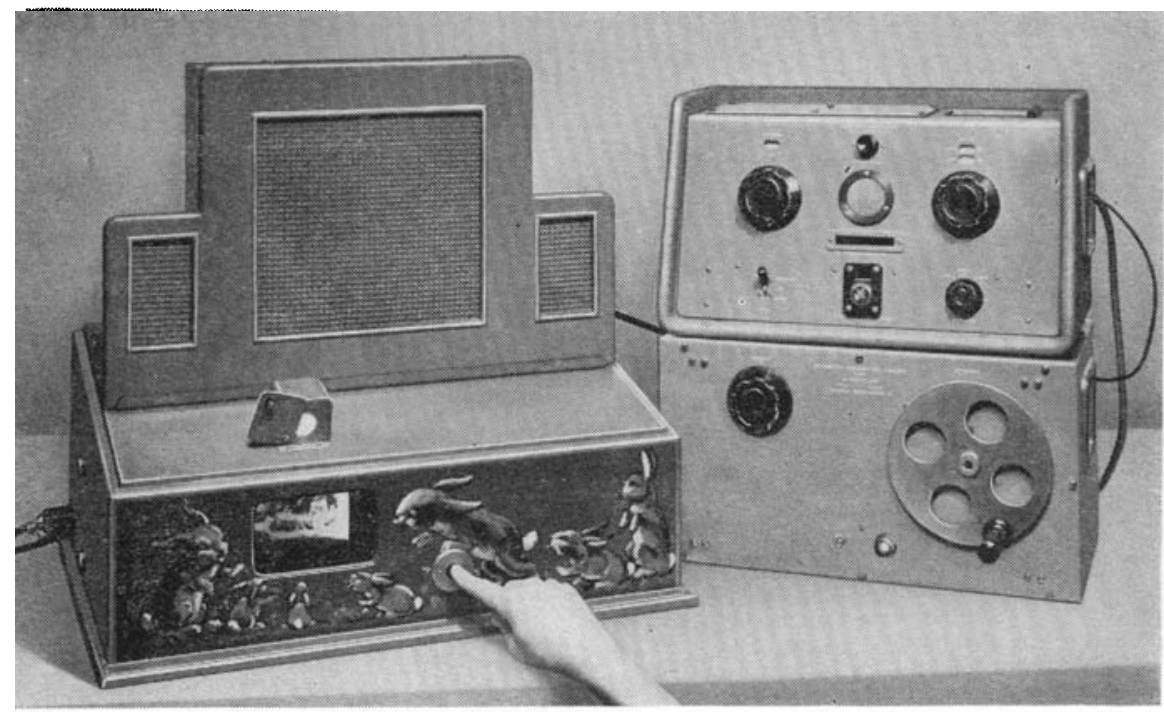

THIS MARCONIAUDIOMETER ASSEMBLY overcomes the familiar difficulties in pure tone audiometry of children. Subject reaction is encouraged by the provision of an interest-feature-a peepshow-which the child quickly learns to operate when the tone is audible, and which is inoperable when no tone is generated. The action of pressing the peepshow button constitutes involuntary acknowledgment of an audible tone from the loudspeaker (which replaces the adult headset). Incorporating the standard Marconi Pure-Tone Audiometer, this is an apparatus making possible ready differentiation between the deaf child and the mentally backward. Audiogram measurement, including preliminary instruction, can be completed in about twenty minutes over the range of 10 preset frequencies: $125 \mathrm{c} / \mathrm{s}$ to $8000 \mathrm{c} / \mathrm{s}$.

\section{Audiometer Assembly for Children OA 215}

\section{MARCONI instruments}

MARCONI INSTRUMENTS LTD., ST. ALBANS, HERTFORDSHIRE

North Eastern: Marconi House, Pudding Chare, Newcastle-on-Tyne O North Western: 38 Pall Mall, Liverpool Midland: co The English Electric Co. Ltd., Central House, New Street, Birmingham - Wales: Marconi House, Mount Stuart Square, Cardiff Scotland: 233 St. Vincent Street, Glasgow $O$ Northern Ireland: A. M. Wedderburn, 41 Donegall Place, Belfast Eire: Kelly \& Shiel, Ltd., United Works, Distillery Road, Dublin 


\section{PRESCRIBE THE EASY EFFECTIVE METHOD}

When spraying, the patient can hold his head in a natural position, yet the solution spreads throughout the nasal cavity, assuring thorough treatment. Effective dropper-application, on the other hand, requires a complicated posture technique which patients are apt to neglect in home treatment.
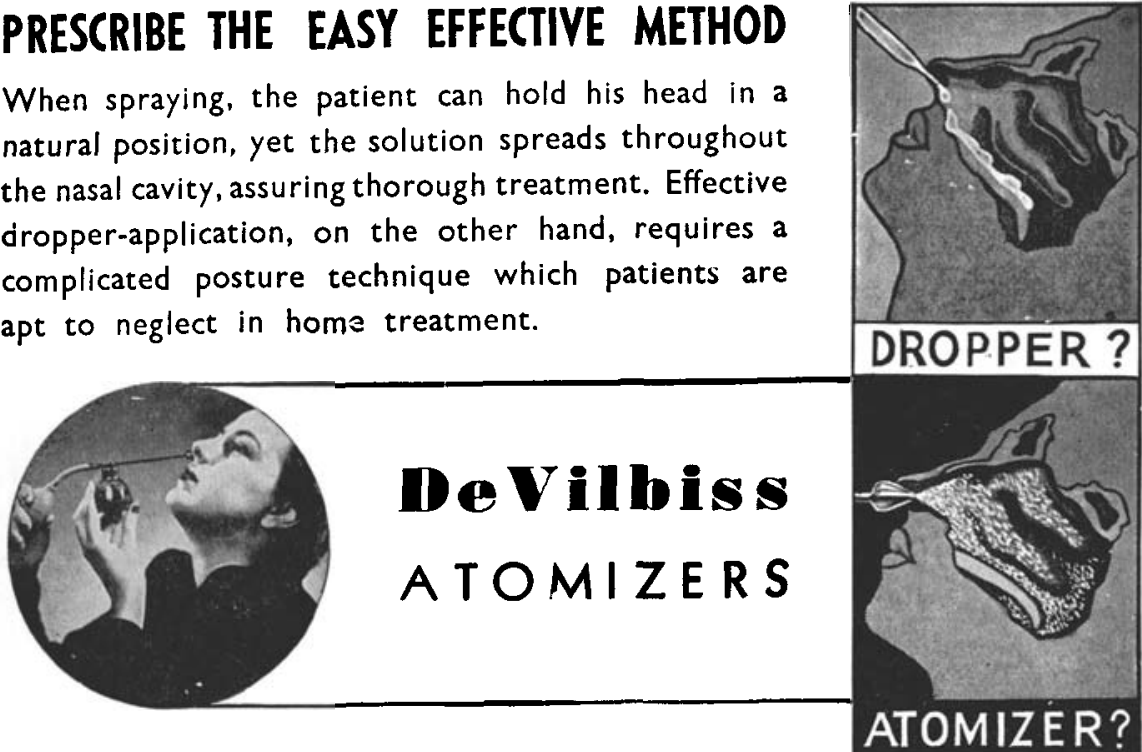

These illustrations, which are based on X-ray research, clearly demonstrate the advantages of the atomizer as compared with the dropper

The AEROGRAPH Co., Ltd., Lower Sydenham, London, S.E.26 Sole Distributors of DeVilbiss Products in the United Kingdom. Telephones: Sydenham 6060-8 Lines.

\section{Mail Your Order Non! \\ PROBLEMS OF THE DEAF}

By MAX A. GOLDSTEIN, M.D., F.A.C.S.

6ro Pages-273 Illustrations-Leather Bound

$\$ 6.00$ Postage prepaid

An unusual, authoritative and comprehensive volume of XIX chapters, covering every phase of work with the Deaf, Deafened and Speech Defective, by an otologist and teacher of 40 years' experience, including :

Chronological History of Deafness-Anatomy and Physiology-Mechanics of Speech-Speech Defects-Cerebral Localization-Hearing Tests-Methods of Instruction-The Acoustic Method-Training of Teachers-The Deaf Child-Hardof-Hearing Child-Physician and Deaf Child-Parent of Deaf Child-Deafened Adult-Hearing Aids-Schools for the Deaf-Quacks and Quackeries-Research.

\section{Published by THE LARYNGOSCOPE PRESS} 640 South Kingshighway ST. LOUIS, MO. 


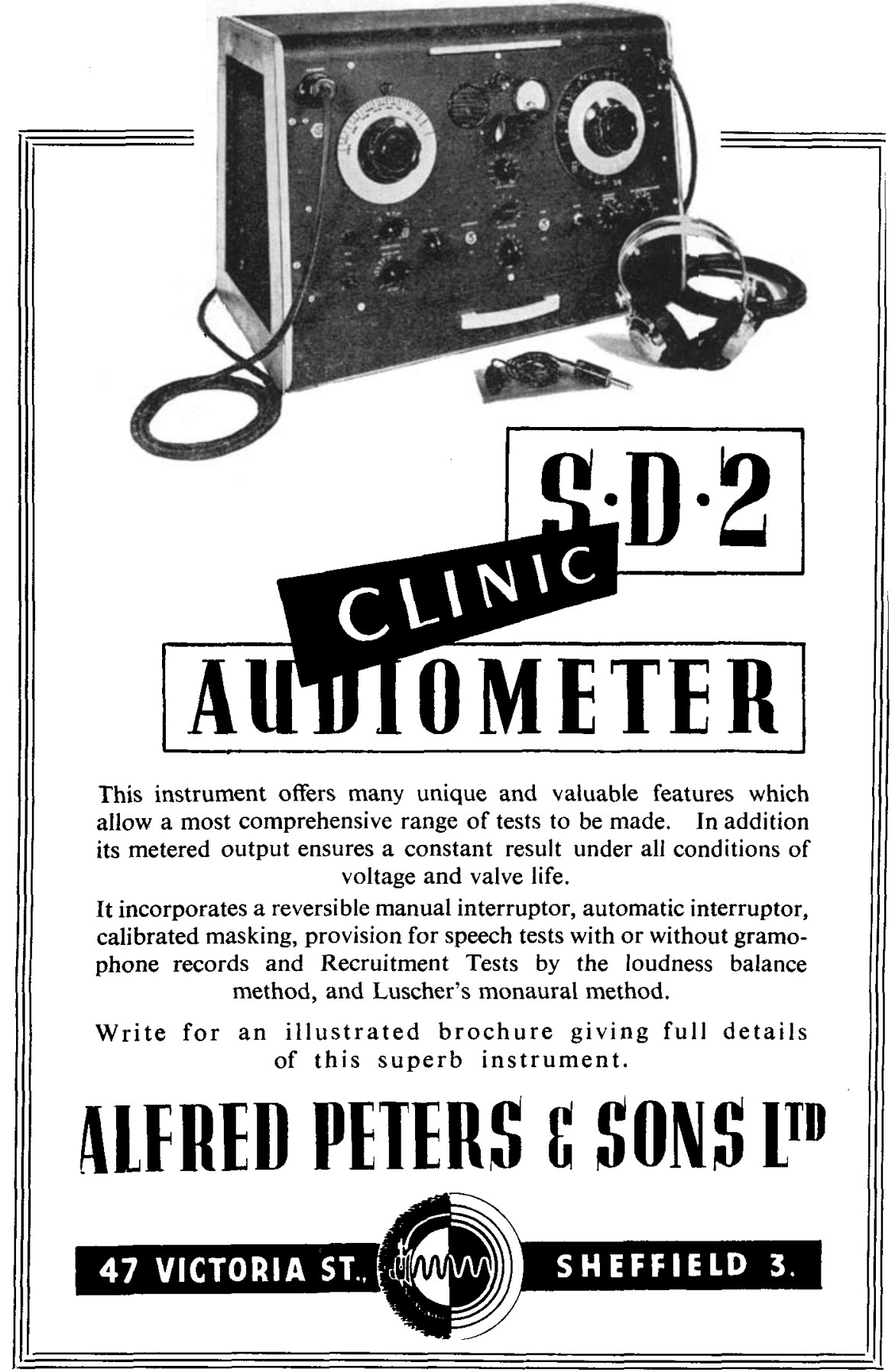

Please mention The Journal of Laryngology when replying to advertisements 


\section{CONTEN'TS}

PACIE

Observations on Abductor Paralysis of the Vocal Cords.

A. F. Williams (Manchester) . . . . . . 397

Some Onservations on the Conduction Mechanism of the Ear. N. W. Gill (London). . . . . . $4^{\circ}$

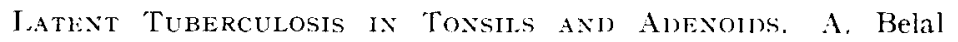
(Alexandria) . . . . . . . . . . $t^{1} t$

I.IPOMA OF THE TARYNX. A. C. Maconie (Windsor) . . . +26)

Cinical RTCORDS-

Iymphosarcoma of the Ethmoid. Alexander R. Harper (Glasgow)

Otogenic Meningitis-A Report of Four Recent Cases. J. L. Appleton (Manchester) . . . . . 437 Societies' Proceedings-

Royal Society of Medicine-Section of Jaryngology . . $\quad \mathrm{H}^{2}$

\section{ARSTRACTS-}

Far Effect of Streptemycin on Vestibular linction. J. R. Bignall, J. W. crofton and 4.58 J. A. B. Thonias.

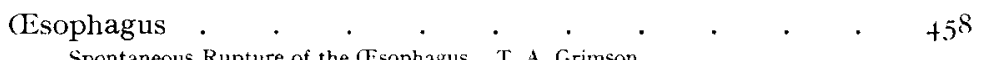
Spontaneous Rupture of the Tsophagus. T. A. Grimson.

Trachea and Bronchi . . . . . . . . 4.59 Endobronchial Lipoma : Report of Case. . John C. Carlisle, William V. Leary
and John R. McDonald.

Miscellaneous . . . . . . . . . . . . . . 460 Malignancy in Adenonas of the Thyroid. F, H, Lahey and H, F, Uare.

For Advertisement space in this Journal apply to : HEADLEY BROTHERS Ltd, 109 Kingsway London W C 2

Please mention The Journal of Laryngology when replying to advertisements 